\title{
Impact of the Coronavirus Disease on Micronutrient Search Trends and Interest in Global Population: A Worldwide Google Trend Analysis
}

\author{
Manoj Reddy Somagutta ${ }^{1,2}$ (D), Namrata Hange ${ }^{2,3 *}$ (D), Atul Wadagale ${ }^{4}$ (D) , Alaa Hassan Yousif Hamdan ${ }^{2}$ (D), \\ Molly Sanjay Jain ${ }^{2,5}$ (D), Sai Harsha Bobba ${ }^{6}$ (D), Erkan Batti ${ }^{6}$ (D), Bernard Emuze ${ }^{7}$ (D)
}

\author{
${ }^{1}$ Department of Medicine, Avalon University School of Medicine, Willemstad, CURACAO \\ ${ }^{2}$ Larkin Community Hospital: South Miami, South Miami, Florida, USA \\ ${ }^{3}$ Eurasian Cancer Research Council (ECRC) Chembur, Mumbai, Maharashtra, INDIA \\ ${ }^{4}$ Department of Community Medicine Vilasrao Deshmukh Government Institute of Medical Sciences, Latur, Maharashtra, INDIA \\ ${ }^{5}$ Department of Medicine, St. James School of Medicine, Park Ridge, Illinois, USA \\ ${ }^{6}$ Department of Medicine, Washington University of Health and Science, San Pedro, BELIZE \\ ${ }^{7}$ Department of Medicine, St. James School of Medicine, Park Ridge, Illinois, USA \\ *Corresponding Author: namratah3@yahoo.co.in
}

Citation: Somagutta MR, Hange N, Wadagale A, Hamdan AHY, Jain MS, Bobba SH, Batti E, Emuze B. Impact of the Coronavirus Disease on Micronutrient Search Trends and Interest in Global Population: A Worldwide Google Trend Analysis. Electron J Gen Med. $2022 ; 19(3): e m 372$. https://doi.org/10.29333/ejgm/11877

ARTICLE INFO

Received: 24 Jul. 2021

Accepted: 24 Nov. 2021

\begin{abstract}
Background: Globally, micronutrient use has increased over the last few decades for disease prevention and holistic health. This article has analyzed the worldwide search trends of micronutrients in the Google Trends (GT) platform to understand the significance and correlation of search trends, comparing the search interests across countries and recognizing the factors involved.
\end{abstract}

Methods: Specific search terms were used to identify the search trends of micronutrients in the GT platform. Statistical analysis was done to evaluate the outcomes of significance and correlation of search terms from 2004 to 2021 by using statistical softwares.

Results: There was a rise in searches for micronutrients vitamin D, vitamin C, zinc, \& iron from 2004 to June 2021 with a steep increase during 2020 correlating with the COVID-19 pandemic. A stable search has been reported in iron searches. Significance and correlation of vitamin D, vitamin C, zinc, \& iron over the years and search interest popularity score of countries for micronutrient searches have been described.

Conclusions: The GT tool can be a necessary tool for healthcare communities and government sectors to understand people's interests, necessities and respond to their concerns accordingly, thus helping us promote population-centric awareness and achieve better evidence-based outcomes.

Keywords: Google trends, micronutrients, vitamin D, vitamin C, zinc, iron, COVID-19

\section{INTRODUCTION}

Nowadays, there is growing attention to the role of the micronutrients in disease prevention, optimizing and maintaining health for holistic health [1,2]. Despite requiring small amounts, consumption of micronutrients is of paramount importance to support at every stage of the immune response [2,3]. Deficiencies of micronutrients suppress immunity by affecting innate and adaptive immunity, augmenting susceptibility to infections [3-5]. Micronutrients deficiencies impair the immune system in battling viral infections and contribute to more virulent strains via genetic alterations of the viral genome $[1,4]$.

Vitamin D (Vit-D) is a known anti-inflammatory, immune booster and antiviral agent that safeguard respiratory health from bacteria and viruses $[1,6,7]$. It mainly inhibits pulmonary inflammatory responses, enhancing innate defence mechanisms against respiratory pathogens [8-10]. Vitamin C (Vit-C), water-soluble immune booster vitamin, and acts as an effective antioxidant to maintain normal immune functions by preventing cell oxidation and inhibiting inflammatory processes [11]. Zinc is recognized to promote antiviral and antibacterial immunity and regulate the inflammatory response [12]. It may reduce the viral replication rate by inhibiting SARS-CoV-2 RNA polymerase or increasing the synthesis of the anti-oxidative enzyme superoxide dismutase, promoting immune functions and helping people resist infectious diseases $[12,13]$. Iron deficiency decreases the ability of the immune system to limit viral infection [3,14]. A significant reduction in morbidity due to upper respiratory tract infections has been associated with iron supplementation [2,9]. These deficiencies are preventable through nutrition education and consumption of a healthy diet containing diverse foods and food fortification and supplementation, where needed [1-4,7]. Coronavirus disease (COVID-19) damages the immune system 
through dysregulation of the macrophage antiviral response, induction of excessive cytokine-mediated immune system responses, activation of complement and coagulation cascades, resulting in enhanced infectivity leading to worse outcomes [5,10,15-17]. During the COVID-19 pandemic, intake of these micronutrients showed a good safety net to improve immunity and fight against the inflammatory process with reducing disease severity $[1,17,18]$. An ecological study has reported correlation of the suboptimal consumption of Vitamin D, Vitamin C, Vitamin B12, and iron with either COVID-19 incidence or mortality indicators; highlighting the importance of Vitamin D and iron for the immune system as well as for the prevention and fight against COVID-19 [19]. One of the observational study have reported low levels of multiple micronutrients in most patients with severe COVID-19 pneumonia- especially low level Vitamin A and zinc [20].

Google search engine is the largest search engine used in the world [21]. Google search terms or topics can be beneficial in understanding the public's interest and perspective. It also helps us assess disease outbreaks' global activity and people's reactiveness and responses [22]. Thus, the key intention of this study is to highlight the worldwide search trends of micronutrient use by utilizing Google Trends (GT) application to understand the significance and correlation of search trends, comparing the search interests across countries and recognize the factors involved.

\section{METHODOLOGY}

GT is an openly available tool dissecting web queries made via the Google search engine and displaying the results on a normalized scale [23]. It determines the proportion of searches for a user-specified term /topic performed on Google. It inspects and delivers data across a specified geographic region and time frame as relative search volume [24]. Relative search volume ranges from 1 to 100 , representing search interest close to the peak popularity for the used search term. A relative search volume (RSV) value of 100 indicates peak popularity, and a score of 0 indicates that the term is below $1 \%$ of its peak popularity [25]. It also analyzes the search interest over time (IoT): Numbers represent search interest relative to the highest point on the chart for the given region and time. A value of 100 is the peak popularity for the term. A value of 50 means that the search term is half as popular. A score of 0 means there was not enough data for this term [24-26]. We set the extraction date to be weekly and extracted data from January 2004 to June 2021. We extracted the search data on June 24-26th, 2020. This allowed for a sufficiently long observation window to review possible changes over the years and in the wake of the pandemic. The initial formulation of the study with the choice for the list of search terms such as micronutrient types and the list of countries to be analyzed. We first searched for userspecified search terms related to the "Coronavirus," "SARSCoV-2," "Vitamin-D," "Vitamin-C," "Zinc," and "Iron," among all searches performed using GTs.

\section{Data Analysis}

Statistical analyses were conducted using Microsoft Excel and R-4.1.0 software with GT R package (developed by Philippe Massicotte, Dirk Eddelbuettel; available link: https://github.com/PMassicotte/gtrendsR) and statistical package for the social sciences (SPSS). Microsoft Excel was used to calculate the mean and standard deviations from the relative search volume data from GTs. We have reviewed the pattern of search after transporting the data into R software. We have conducted ANOVA test followed by linear regression, multivariate logistic regression analysis and spearman correlation coefficient using SPSS.

We estimate the relationship between given micronutrients by using line regression equation as below:

$$
\hat{Y}=b_{0}+b_{1}+\cdots+b_{n}+\epsilon_{i},
$$

where $b_{0}$ and $b_{1}$ are coefficients; $x_{i}$ is micronutrients- Vitamin D, Vitamin C, zinc, and iron; and $\epsilon$ is error or residual term i.e. difference between observed and predicted $Y$ value.

We have reviewed interest over the time and geographical locations using the data and visuals using the GT. Search interest over time for specific micronutrients across geographical locations is also gathered.

\section{RESULTS}

\section{Trends of "Vitamin D, Vitamin C, Zinc and Iron" Across Countries since January 2004 to June 2021}

Mean searches for Vit-D, Vit-C, zinc and iron from January 2004 to June 2021 were $3.80 \pm 1.96,3.49 \pm 2.09,5.02 \pm 1.19$, and $44.63+7.71$, respectively (Table 1 ). Looking at searches for micronutrients over 2004 to June 2021, there was a rise in VitD, Vit-C, and Zinc since 2004, a peculiar surge in searches noted over 2020 as presented in the Figure 1.

Table 1. Year wise mean and SD for micronutrients

\begin{tabular}{|c|c|c|c|c|}
\hline Year & Vitamin D & Vitamin C & Zinc & Iron \\
\hline 2004 & $1 \pm 0$ & $2.67 \pm 0.65$ & $5.75 \pm 0.45$ & $43.67 \pm 1.37$ \\
\hline 2005 & $1.08 \pm 0.29$ & $2.50 \pm 0.52$ & $5.67 \pm 0.65$ & $43.17 \pm 2.21$ \\
\hline 2006 & $1.08 \pm 0.29$ & $2.33 \pm 0.49$ & $5.25 \pm 0.62$ & $39.33 \pm 1.87$ \\
\hline 2007 & $1.75 \pm 0.45$ & $2.00 \pm 0.00$ & $4.67 \pm 0.49$ & $37.58 \pm 1.62$ \\
\hline 2008 & $2.08 \pm 0.29$ & $2.00 \pm 0.00$ & $4.58 \pm 0.51$ & $48.58 \pm 13.88$ \\
\hline 2009 & $3.17 \pm 0.39$ & $2.17 \pm 0.39$ & $4.50 \pm 0.52$ & $40.92 \pm 2.19$ \\
\hline 2010 & $3.83 \pm 0.39$ & $2.00 \pm 0.00$ & $4.25 \pm 0.45$ & $50.17 \pm 13.99$ \\
\hline 2011 & $3.67 \pm 0.49$ & $2.33 \pm 0.49$ & $4.33 \pm 0.49$ & $39.83 \pm 1.59$ \\
\hline 2012 & $4.17 \pm 0.39$ & $2.75 \pm 0.45$ & $4.08 \pm 0.29$ & $46.50 \pm 3.75$ \\
\hline 2013 & $4.0 \pm 0.51$ & $2.92 \pm 0.29$ & $4.42 \pm 0.51$ & $56.50 \pm 16.94$ \\
\hline 2014 & $4.17 \pm 039$ & $3.00 \pm 0.00$ & $4.33 \pm 0.49$ & $44.08 \pm 1.73$ \\
\hline 2015 & $4.42 \pm 0.51$ & $3.42 \pm 0.51$ & $4.50 \pm 0.52$ & $44.67 \pm 2.15$ \\
\hline 2016 & $4.67 \pm 0.49$ & $3.75 \pm 0.45$ & $4.75 \pm 0.45$ & $44.58 \pm 2.91$ \\
\hline 2017 & $4.83 \pm 0.72$ & $4.00 \pm 0.00$ & $5.00 \pm 0.43$ & $43.75 \pm 4.65$ \\
\hline 2018 & $5.33 \pm 0.65$ & $4.42 \pm 0.51$ & $5.00 \pm 0.00$ & $43.92 \pm 2.57$ \\
\hline 2019 & $5.42 \pm 0.51$ & $5.08 \pm 0.29$ & $5.33 \pm 0.49$ & $46.25 \pm 5.21$ \\
\hline 2020 & $7.75 \pm 1.06$ & $9.42 \pm 2.81$ & $8.17 \pm 1.47$ & $44.92 \pm 2.71$ \\
\hline 2021 & $8.00 \pm 1.41$ & $8.83 \pm 0.75$ & $8.00 \pm 0.63$ & $45.50 \pm 1.76$ \\
\hline Total & $3.80 \pm 1.96$ & $3.50 \pm 2.10$ & $5.06 \pm 1.19$ & $44.64 \pm 7.72$ \\
\hline
\end{tabular}

There was a stable trend in Iron searches over the years. VitD searches have risen eight-fold since 2004, with a slow, steady, sharp rise in 2020 of $40 \%$. This rise continued further in 2021. Countries that have recorded the highest IoT in searching for Vit-D are Norway, United Arab Emirates, United Kingdom, Germany, and the United States. At the same time, Japan, Mexico, Brazil, France and Spain reported the lowest loT. Vit-C searches have increased fourfold since 2004. These searches noted a peak in 2020 with an $85 \%$ rise. This trend subsequently started declining in 2021. Malaysia, the Philippines, Jamaica, Trinidad \& Tobago, and Ghana reported the highest interest. Countries that have recorded the lowest IoT in searching for 
Vit-C are Brazil, Japan, France, Russia, and Mexico. Zinc searches have risen close to two-fold since 2004. These searches noted a peak in 2020 with a rise of $53 \%$ and started declining in 2021. Brazil, Russia, Japan, Italy, and Poland report the lowest IoT, while Nicaragua, Bolivia, Chile, Ghana, and Panama reported the highest interest over time. Iron searches noted a stable rise since 2004. There was a drop in Iron searches during the year 2020. The United States, Australia, Canada, New Zealand, and the United Kingdom reported the highest interest, while Japan, Taiwan, China, Iran, and Ukraine reported the lowest loT.

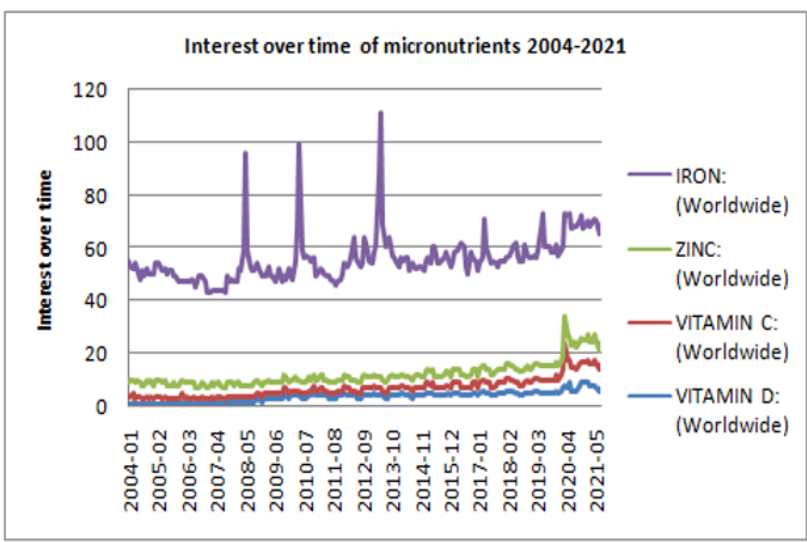

Figure 1. Trend of searches of Vit D, Vit C, zinc, and iron since 2004-2021

\section{Significance and Correlation of Vit-D, Vit-C, Zinc \& Iron Over Years}

A residual plot with residuals on the $x$-axis and fitted values (Vit-D, Vit-C, zinc and iron) on the $y$-axis are examined to understand the correlational analysis model. Figure 2 signifies that the residuals are randomly distributed around the horizontal access indicating the relationship between the independent and the dependent variables are linear, thus directing us to use an appropriate linear regression model.

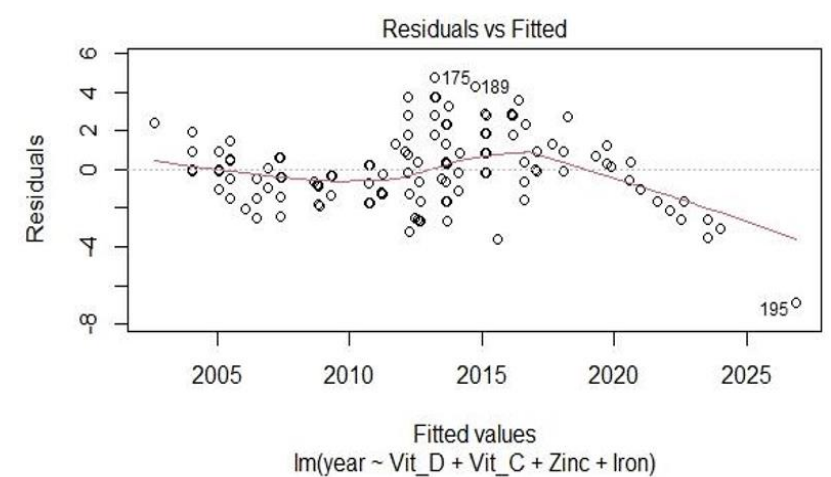

Figure 2. Residual plot depicting correlation of trend of searches of Vit D+ Vit C+zinc+iron since 2004-2021

The multivariate linear regression model is used to test the significance of the dependent variable and the predictors. Coefficient and residual statistics, spearman rank correlations were calculated using SPSS. The multivariate linear analysis is done considering the independent variable as the year and then the explanatory variable is Vit-D, Vit-C, zinc, and iron (Table 2). The $p$-value was $<0.0001$ for Vit-D, Vit-C, and zinc, indicating statistical significance, so there is a significant increase in search trends for Vit-D, Vit-C, and a significant decrease in search trends for zinc over the years. For iron, $p$ value is $>0.05$. The coefficient is not statistically significant, meaning there is no significant increase in iron search over the recent years.

Table 2. Significance of Vit-D, Vit-C, zinc, and iron GT searches since 2004-2021

\begin{tabular}{cccccc}
\hline \multicolumn{7}{c}{ Coefficients } \\
\hline \multirow{2}{*}{ Model } & $\begin{array}{c}\text { Unstandardized } \\
\text { coefficients }\end{array}$ & $\begin{array}{c}\text { Standard } \\
\text { coeficients }\end{array}$ & \multirow{2}{*}{$\mathrm{t}$} & Sig. \\
\cline { 2 - 5 } & $\mathrm{B}$ & Std. error & Beta & & \\
\hline (Constant) & 2008.869 & 1.112 & & 1806.240 & .00 \\
\hline Vitamin D & 1.915 & .112 & .741 & 17.089 & .00 \\
\hline 1 Vitamin C & 1.010 & .157 & .418 & 6.427 & .00 \\
\hline Zinc & -1.434 & .198 & -.337 & -7.236 & .00 \\
\hline Iron & -.004 & .016 & -.005 & -.221 & .82 \\
\hline Dependent variable: year & & & &
\end{tabular}

We also calculated the T-test, F-statistic, and $\mathrm{R}^{2}$ (coefficient of determination) and residual statistics in $\mathrm{R}$ software. The multiple regression's $R^{2}$ was 0.8788 , and the adjusted $R^{2}$ was 0.8764 . An $R^{2}$ is closer to 1 indicates that the majority of the dependent variables are dispersed to uncertainty, which can be explained by the regression equation, indicating better goodness of fit.

Spearman's rho coefficient was calculated to express the strength of association between the four micronutrients. From the Table 3 by using spearman's rho correlations for four micronutrients, we can conclude that there is a statistical significance difference between Vit-D with Vit-C $(p<0.01)$, zinc $(p<0.05)$, iron $(p<0.01)$, Vit- $C$ with zinc $(p<0.01)$ and iron $(p<0.01)$. However, there is no significance between iron with zinc $(p>0.05)$.

Table 3. Spearman correlation between the micronutrients

\begin{tabular}{cccccc}
\hline \multicolumn{7}{c}{ Spearman correlation coefficients } \\
\hline \multirow{2}{*}{ Model } & $\begin{array}{c}\text { Unstandardized } \\
\text { coefficients }\end{array}$ & $\begin{array}{c}\text { Standard } \\
\text { coeficients }\end{array}$ & \multirow{2}{*}{$\mathrm{t}$} & \multirow{2}{*}{ Sig. } \\
\cline { 2 - 5 } & $\mathrm{B}$ & Std. error & Beta & & \\
\hline (Constant) & 2008.869 & 1.112 & & 1806.240 & .000 \\
\hline Vitamin D & 1.915 & .112 & .741 & 17.089 & .000 \\
\hline Vitamin C & 1.010 & .157 & .418 & 6.427 & .000 \\
\hline Zinc & -1.434 & .198 & -.337 & -7.236 & .000 \\
\hline Iron & -.004 & .016 & -.005 & -.221 & .825 \\
\hline
\end{tabular}

Dependent variable: year

\section{Popularity of Vit-D, Vit-C, Zinc and Iron by Countries}

Countries that have recorded the highest IoT in searching for Vit-D are Norway, United Arab Emirates, United Kingdom, Germany, and the United States, while Japan, Mexico, Brazil, France, and Spain reported the lowest IoT. Malaysia, the Philippines, Jamaica, Trinidad \& Tobago, and Ghana reported the highest interest in searching Vit-C. Countries that have recorded the lowest loT in searching for Vit-C are Brazil, Japan, France, Russia, and Mexico. Brazil, Russia, Japan, Italy, and Poland report the lowest loT for zinc search, while Nicaragua, Bolivia, Chile, Ghana, and Panama reported the highest interest over time. The United States, Australia, Canada, New Zealand, and the United Kingdom reported the highest interest in searches for iron, while Japan, Taiwan, China, Iran, and Ukraine reported the lowest loT (Table 4). 
Table 4. Search interest popularity score of countries for micronutrient searches

\begin{tabular}{|c|c|c|c|c|}
\hline Micronutrient & $\begin{array}{c}\text { Countries } \\
\text { with high } \\
\text { interest }\end{array}$ & Popularity & $\begin{array}{l}\text { Countries } \\
\text { with low } \\
\text { interest }\end{array}$ & Popularity \\
\hline \multirow{5}{*}{ Vitamin D } & Norway & 100 & Spain & 3 \\
\hline & $\begin{array}{c}\text { United Arab } \\
\text { Emirates }\end{array}$ & 96 & France & 2 \\
\hline & $\begin{array}{c}\text { United } \\
\text { Kingdom }\end{array}$ & 92 & Brazil & 2 \\
\hline & Germany & 84 & Mexico & 2 \\
\hline & United States & 84 & Japan & 1 \\
\hline \multirow{5}{*}{ Vitamin C } & Malaysia & 100 & Mexico & 2 \\
\hline & Philippines & 70 & Russia & 1 \\
\hline & Jamaica & 67 & France & 1 \\
\hline & $\begin{array}{c}\text { Trinidad \& } \\
\text { Tobago }\end{array}$ & 61 & Japan & 1 \\
\hline & Ghana & 59 & Brazil & 1 \\
\hline \multirow{5}{*}{ Zinc } & Nicaragua & 100 & Poland & 4 \\
\hline & Bolivia & 87 & Italy & 4 \\
\hline & Chile & 80 & Japan & 3 \\
\hline & Ghana & 78 & Russia & 3 \\
\hline & Panama & 76 & Brazil & 3 \\
\hline \multirow{5}{*}{ Iron } & United States & 100 & Ukraine & 10 \\
\hline & Australia & 97 & Iran & 10 \\
\hline & Canada & 92 & Taiwan & 9 \\
\hline & New Zealand & 85 & China & 7 \\
\hline & $\begin{array}{c}\text { United } \\
\text { Kingdom }\end{array}$ & 82 & Japan & 4 \\
\hline
\end{tabular}

Popularity: Relative search volume (RSV), which is a measure of the number of searches for a chosen term compared to the number of searches for all other terms over a selected time period

\section{DISCUSSION}

This is one of the unique studies that have explored the growing evidence of people's interest in micronutrient searches using an online platform, Google trends. Our analysis shows a steady rise in micronutrient searches for Vit-C, Vit-D, and zinc since 2004. A steep climb in the search popularity of micronutrients -Vit-C, Vit-D, and zinc has been observed during 2020-2021, correlating it with the COVID-19 pandemic. These micro nutrients' search trends could reflect increasing concern that translates into population behaviour of increased usage of these micronutrients. Google searches for "micronutrients," along with other keywords "Vitamin D," "Vitamin C," "zinc," and "iron," which reached an all-time high in February 2020. This is more important and relevant to COVID-19 spread, also increased but not in the magnitude of the search for "micronutrients."

Vit-D searches have risen by eight-fold in 2020-21 since 2004 while nearly doubling throughout 2019-2021. This increase directly correlates with the significant rise during the pandemic. Vit-D searches were highest in Norway, United Arab Emirates, United Kingdom, Germany, and the United States. Figure 3 depicts the popularity of Vit-D across the countries. The search was prominent in the first world nations deprived of sunlight. Low Vit-D status is seen in Norway, United Kingdom, Germany, United States, and other Nordic countries during winter due to inadequate sun exposure from October to March [26-28]. These searches were highest in the United Arab Emirates (UAE), with a high prevalence of hypovitaminosis $D$, despite abundant sunlight [29]. This probably was pointed towards people's curiosity about the effectiveness of Vit-D during COVID-19. It has possibly translated into their

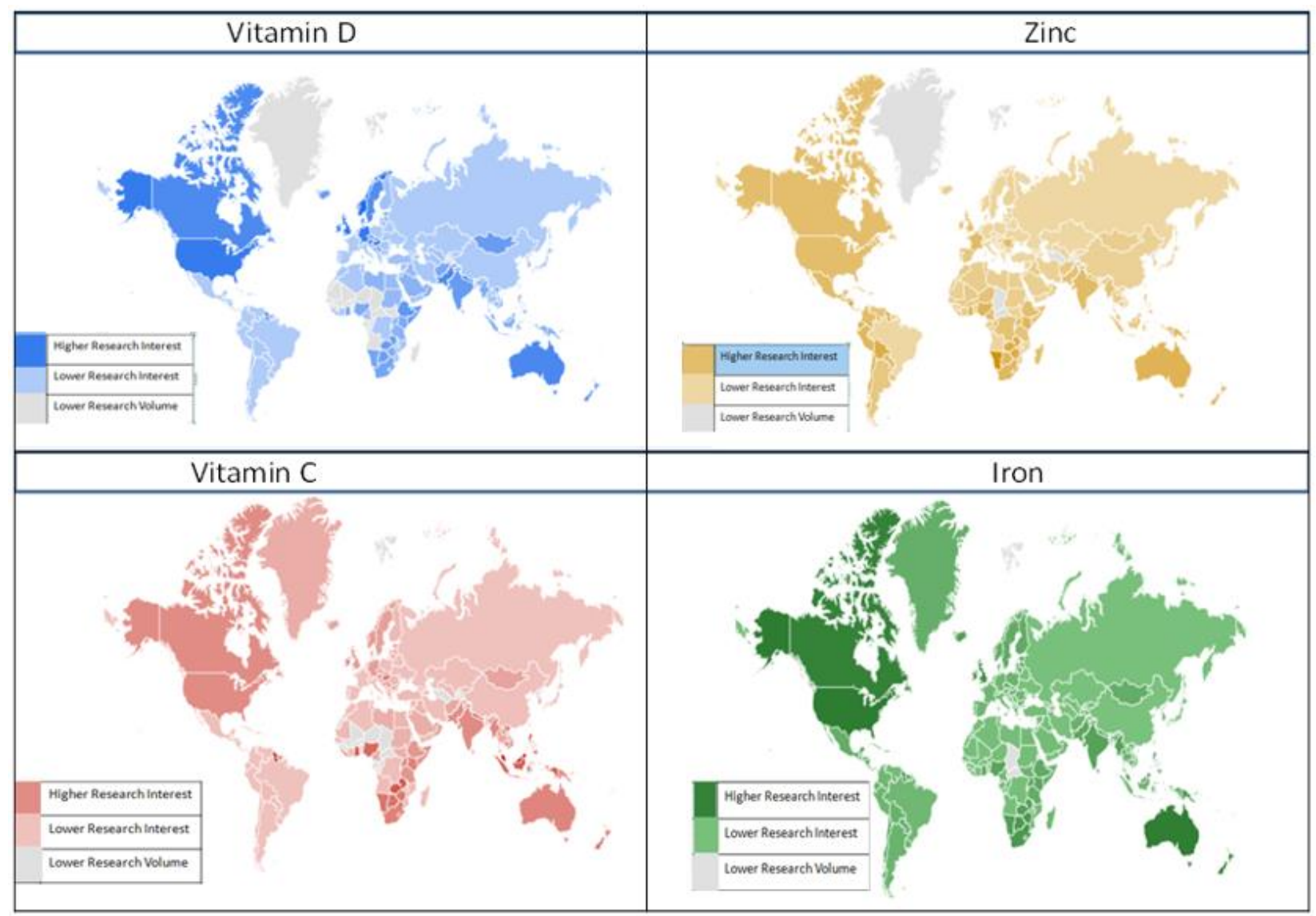

Figure 3. Worldwide graphic map of search term popularity for "Vitamin D, Vitamin C, zinc, and iron" by location 
behaviour, reflecting increased Vit-D supplements usage or exposure to sunlight. During COVID-19, this search might have reached its peak by the research pointing out the significant association between Vit-D deficiency and COVID-19 infection, the mortality rate of COVID-19 among European countries $[26,27]$. Interestingly, low searches were prominent in Japan, Mexico, Brazil, France, and Spain in Vit-D deficient or insufficient countries [27-34].

Vit-C searches have increased fourfold since 2004, with doubled searches during the pandemic with an $85 \%$ rise. This trend subsequently started declining in 2021. Malaysia, the Philippines, Jamaica, Trinidad \& Tobago, and Ghana reported the highest popularity. This correlates with Vit-C deficiency in low-income groups and low-middle income countries requiring supplementation. These are countries with progressively growing and expanding health care systems. This search has been extensive in developing countries, considering Vit-C's readily available and cost-effective dietary resources [35]. Most developed countries, including Brazil, Japan, France, Russia, and Mexico, reported the lowest Vit-C searches.

Zinc searches have risen close to two-fold since 2004. These searches noted a peak during the COVID-19 pandemic with a rise of 53\% and started declining in 2021.The highest investigations for zinc were reported in populous countries in America, including Nicaragua, Bolivia, Chile and Panama. The national health and nutrition survey conducted in the US has reported zinc deficiency in specific targeted population groups like pregnant women, the elderly and adolescents [36]. The severity and mortality of COVID-19 were closely correlated with serum iron levels. Low serum iron concentration was an independent risk factor for death in COVID-19 patients [37]. Despite this, there was a stable marginal rise in iron search since 2004. On the contrary, there was a drop in iron searches during the pandemic time. This is possible because of existing policies of regular iron supplementation in pregnant women, children and malnourished patients. There is a significant increase in Vit-D, Vit-C searches with $p$-value search over the recent years is $<0.0001 \&$ significant decrease in zinc searches. This significant rise in Vit-D and Vit-C can correlate with the COVID-19 pandemic and people's awareness about their health, while there is no significant increase in iron search over the recent years. As iron supplementation is standard in pregnant women and malnourished, possibly that has resulted in an almost stable trend in searches.

This research article has the strength of using GTs being aggregated (grouped), anonymized (no one is personally identified) and categorized (determining the topic for a search query). This research also comes with some limitations of using GTs for analysis. This data represents the Google search trends and popularity but does not correlate with the actual data of the world's prevalence of micronutrient use, so a strict association cannot be made with the search interest and reallife utility. This study of real-time data from GTs and existing dataset analysis shows that popularity has led to the respective micronutrient use among the population.

\section{CONCLUSIONS}

GT searches of micronutrients have increased globally over the last two decades, especially during the COVID-19 pandemic. A significant increase in Vit-D and Vit-C search trends during the pandemic shows population interest and may reflect people's usage. Further epidemiological studies are required to assess the extent of global micronutrient use associated with the COVID-19 pandemic as supplementation for therapeutic purposes. The GT tool can be a necessary tool for health care workers to understand people's interests as necessities and respond to their concerns accordingly, thus helping the health care workers to promote population-centric awareness and achieve better evidence-based outcomes.

Author contributions: All authors have sufficiently contributed to the study, and agreed with the results and conclusions.

Funding: No funding source is reported for this study.

Ethical approval: This research did not need any formal approval from the ethical committee.

Declaration of interest: No conflict of interest is declared by authors.

\section{REFERENCES}

1. Godswill AG, Somtochukwu IV, Ikechukwu AO, Kate EC. Health benefits of micronutrients (vitamins and minerals) and their associated deficiency diseases: a systematic review. Int J Food Sci. 2020;3(1):1-32. https://doi.org/ 10.47604/ijf.1024

2. Wishart K. Increased micronutrient requirements during physiologically demanding situations: review of the current evidence. Vitam Miner. 2017;6(2): 1000166. https://doi.org/ 10.4172/2376-1318.1000166

3. Gombart AF, Pierre A, Maggini S. A review of micronutrients and the immune system-working in harmony to reduce the risk of infection. Nutrients. 2020;12(1):236. https://doi.org/ 10.3390/nu12010236 PMid:31963293 PMCid:PMC7019735

4. Pecora F, Persico F, Argentiero A, Neglia C, Esposito S. The role of micronutrients in support of the immune response against viral infections. Nutrients. 2020;12(10):3198. https://doi.org/10.3390/nu12103198

5. Patel J, Patel A. The role of nutritional factors in pathogenesis of diseases. In Pathak YV, Ardekani AM, editors. Nutrigenomics and nutraceuticals. CRC Press, 2017. p. 483-514. https://doi.org/10.1201/978131515371119 PMid:28500896 PMCid:PMC5429244

6. Bishop EL, Ismailova A, Dimeloe S, Hewison M, White JH. Vitamin D and immune regulation: antibacterial, antiviral, anti-inflammatory. JBMR Plus. 2021;5(1):e10405. https://doi.org/10.1002/jbm4.10405 PMid:32904944 PMCid:PMC7461279

7. Maes K, Serré J, Mathyssen C, Janssens W, Gayan-Ramirez G. Targeting vitamin D deficiency to limit exacerbations in respiratory diseases: utopia or strategy with potential? Calcif Tissue Int. 2020;106(1):76-87. https://doi.org/ 10.1007/s00223-019-00591-4 PMid:31350569

8. Grant WB, Lahore H, McDonnell SL, et al. Evidence that vitamin $D$ supplementation could reduce risk of influenza and COVID-19 infections and deaths. Nutrients. 2020;12(4):988. https://doi.org/10.3390/nu12040988 PMid: 32252338 PMCid:PMC7231123

9. Raz G, Esposito S, Ganmaa D, et.al. Vitamin D supplementation to prevent acute respiratory tract infections: systematic review and meta-analysis of individual participant data. BMJ. 2017;356:i6583. https://doi.org/10.1136/bmj.i6583.3 PMid:28202713 PMCid:PMC5310969 
10. McAuliffe S, Ray S, Fallon E, Bradfield J, Eden T, Kohlmeier M. Dietary micronutrients in the wake of COVID-19: an appraisal of evidence with a focus on high-risk groups and preventative healthcare. BMJ NPH. 2020;3(1):93. https://doi.org/10.1136/bmjnph-2020-000100 PMid:33235973 PMCid:PMC7664499

11. Hemilä $\mathrm{H}$, Chalker E. Vitamin $\mathrm{C}$ for preventing and treating the common cold. Cochrane Database Syst Rev. 2013;2013(1):CD000980. https://doi.org/10.1002/14651858 .CD000980 PMid:23440782 PMCid:PMC8078152

12. Read SA, Obeid S, Ahlenstiel C, et al. The role of zinc in antiviral immunity. Adv Nutr. 2019;10:696-710. https://doi.org/10.1093/advances/nmz013 PMid:31305906 PMCid:PMC6628855

13. Skalny AV, Rink L, Ajsuvakova OP, et al. Zinc and respiratory tract infections: perspectives for COVID-19 (review). Int J Mol Med. 2020;46(1):17-26. https://doi.org/10.3892/ ijmm.2020.4575 PMidD:32319538 PMCid:PMC7255455

14. Silva AD, Atukorala S, Weerasinghe I, Ahluwalia N. Iron supplementation improves iron status and reduces morbidity in children with or without upper respiratory tract infections: a randomized controlled study in Colombo, Sri Lanka. Am J Clin Nutr. 2003;77(1):234-41. https://doi.org/10.1093/ajcn/77.1.234 PMid:12499347

15. Sonia SF, Haque MF, Sultana A, Parvin R, Afroze S. Iron deficiency anemia and respiratory tract infections in children: a review. Journal of Dr. MR Khan Shishu (Children) Hospital. 2020;1(1).

16. Gorji A, Ghadiri MK. The potential roles of micronutrient deficiency and immune system dysfunction in COVID-19 pandemic. Nutrition. 2020;6:111047. https://doi.org/ 10.1016/j.nut.2020.111047 PMid:33277150 PMCid: PMC7647394

17. Richardson DP, Lovegrove JA. Nutritional status of micronutrients as a possible and modifiable risk factor for COVID-19: a UK perspective. Br J Nutr. 2021;125(6):678-84. https://doi.org/10.1017/S000711452000330X PMid: 32815493 PMCid:PMC7492581

18. Wang MX, Gwee SX, Pang J. Micronutrients deficiency, supplementation and novel Coronavirus infections-a systematic review and meta-analysis. Nutrients. 2021;13(5):1589. https://doi.org/10.3390/nu13051589 PMid:34068656 PMCid:PMC8151981

19. Galmés S, Serra F, Palou A. Current state of evidence: influence of nutritional and nutrigenetic factors on immunity in the COVID-19 pandemic framework. Nutrients. 2020;12(9):2738. https://doi.org/10.3390/nu12092738 PMid:32911778 PMCid:PMC7551697

20. Tomasa-Irriguible TM, Bielsa-Berrocal L, Bordejé-Laguna L, et al. Low levels of few micronutrients may impact COVID19 disease progression: an observational study on the first wave. Metabolites. 2021;11(9):565. https://doi.org/ 10.3390/metabo11090565

21. Forsey C. The top 7 search engines, ranked by popularity. Available at: https://blog.hubspot.com/marketing/topsearch-engines

22. Ginsberg J, Mohebbi MH, Patel RS, Brammer L, Smolinski MS, Brilliant L. Detecting influenza epidemics using search engine query data. Nature. 2009;457(7232):1012-4. https://doi.org/10.1038/nature07634 PMid:19020500

23. Support.google.com. Trends help. 2019. Available at: https://support.google.com/trends\#topic=6248052
24. Dey M, Zhao SS. COVID-19 and Kawasaki disease: an analysis using Google Trends. Clin Rheumatol. 2020;39(8):2483-4. https://doi.org/10.1007/s10067-02005231-z PMid:32557254 PMCid:PMC7298164

25. Flanagan R, Kuo B, Staller K. Utilizing Google Trends to assess worldwide interest in irritable bowel syndrome and commonly associated treatments. Dig Dis Sci. 2021;66(3):814-22. https://doi.org/10.1007/s10620-02006290-7 PMid:32361922

26. Kimlin MG. Geographic location and vitamin D synthesis. Mol Aspects Med. 2008;29(6):453-61. https://doi.org/ 10.1016/j.mam.2008.08.005 PMid:18786559

27. Merlo C, Trummler M, Essig S, Zeller A. Vitamin D deficiency in unselected patients from Swiss primary care: a crosssectional study in two seasons. PLoS One. 2015;10(9):e0138613. https://doi.org/10.1371/journal. pone.0138613 PMid:26372355 PMCid:PMC4570784

28. Benhamou J, Schindler C, Rutishauser J. Prevalence of vitamin $D$ deficiency in an inpatient population in the Swiss Canton of Basel-Country. Swiss Med Wkly. 2021; 151:w20470. https://doi.org/10.4414/smw.2021.20470 PMid:33714209

29. Sridhar SB, Rao PG, Multani SK, Jain M. Assessment of prevalence of hypovitaminosis $D$ in multiethnic population of the United Arab Emirates. J Adv Pharm Technol Res. 2016;7(2):48-53. https://doi.org/10.4103/2231-4040.177202 PMid:27144152 PMCid:PMC4850768

30. Bakaloudi DR, Chourdakis M. Is vitamin D deficiency associated with the COVID-19 epidemic in Europe? medRxiv. 2021. https://doi.org/10.1101/2021.01.28. 21250673

31. González-Molero I, Morcillo S, Valdés S, Pérez-Valero V, Botas P, Delgado E, et.al. Vitamin D deficiency in Spain: a population-based cohort study. Eur J Clin Nutr. 2011;65(3):321-8. https://doi.org/10.1038/ejcn.2010.265 PMid:21179052

32. Souberbielle JC, Massart C, Brailly-Tabard S, Cavalier E, Chanson P. Prevalence and determinants of vitamin D deficiency in healthy French adults: the VARIETE study. Endocrine. 2016;53(2):543-50. https://doi.org/10.1007/ s12020-016-0960-3 PMid:27106800

33. Martínez-Zavala N, López-Sánchez GN, Vergara-Lopez A, et al. Vitamin $D$ deficiency in mexicans have a high prevalence: a cross-sectional analysis of the patients from the Centro Médico Nacional 20 de Noviembre. Arch Osteoporos. 2020; 15(1):1-5. https://doi.org/10.1007/s11657-020-00765-w PMid:32542548

34. Asakura K, Etoh N, Imamura $\mathrm{H}$, et al. Vitamin D status in Japanese adults: relationship of serum 25-hydroxyvitamin D with simultaneously measured dietary vitamin D intake and ultraviolet ray exposure. Nutrients. 2020;12(3):743. https://doi.org/10.3390/nu12030743 PMid:32168939 PMCid:PMC7146414

35. Rowe S, Carr AC. Global vitamin C status and prevalence of deficiency: a cause for concern? Nutrients. 2020;12(7):2008. https://doi.org/10.3390/nu12072008 PMid:32640674 PMCid:PMC7400810

36. Briefel RR, Bialostosky K, Kennedy-Stephenson J, McDowell MA, Ervin RB, Wright JD. Zinc intake of the US population: findings from the third national health and nutrition examination survey, 1988-1994. J Nutr. 2000; 130(5):1367S-73S. https://doi.org/10.1093/jn/130.5.1367S PMid:10801945 
37. Zhao K, Huang J, Dai D, Feng Y, Liu L, Nie S. Serum iron level as a potential predictor of coronavirus disease 2019 severity and mortality: a retrospective study. Open Forum Infect Dis. 2020;7(7):ofaa250. https://doi.org/10.1093/ ofid/ofaa250 PMid:32661499 PMCid:PMC7337740 